\title{
HAMBATAN PADA PENGADAAN JASA KONSULTAN SECARA E-SELEKSI DI PEMERINTAH PROVINSI DKI JAKARTA
}

\author{
Putra Hidayat ${ }^{1}$, Sarwono Hardjomuljadi² dan Mawardi Amin³
}

\author{
${ }^{1}$ Prodi Teknik Sipil Universitas Mercu Buana Jakarta, Jl. Meruya Selatan No.7 Jakarta 11620 \\ Email korespondensi: phidayat77@gmail.com \\ 1Prodi Teknik Sipil Universitas Mercu Buana Jakarta, Jl. Meruya Selatan No.7 Jakarta 11620 \\ Email : sarwonohm2@yahoo.co.id \\ 1Prodi Teknik Sipil Universitas Mercu Buana Jakarta, Jl. Meruya Selatan No.7 Jakarta 11620
}

Email : mawardi.a@gmail.com

\begin{abstract}
ABSTRAK
Pengadaan merupakan suatu kegiatan yang berkaitan dengan pemenuhan/penyediaan (barang atau jasa) pada suatu proyek tertentu. Pengadaan barang/jasa atau yang lebih dikenal dengan lelang atau seleksi (procurement) telah banyak dilakukan oleh semua pihak baik dari pemerintah maupun swasta. Hambatan yang terjadi pada lelang bisa disebabkan oleh berbagai faktor dari pihak - pihak terkait (stakeholders), baik dari pengguna anggaran, unit layanan pengadaan barang/jasa pemerintah maupun dari pihak rekanan yang mengikuti proses pengadaan barang / jasa pemerintah. Dengan banyak terjadinya kegagalan lelang, maka perlu dilakukan analisis terhadap faktor -faktor apa saja yang mempengaruhi hambatan proses lelang yang dilakukan secara elektronik di Pemerintah Provinsi DKI Jakarta dengan mengambil sampel penelitian pada, pengguna jasa dan penyedia jasa yang merupakan perusahaan konsultan yang mengikuti proses lelang pada paket - paket kegiatan yang mengalami gagal lelang selama dilakukannya proses pengadaan barang dan jasa secara elektronik di Pemerintah Provinsi DKI Jakarta. Penelitian ini bertujuan untuk mencari mengidentifikasi faktor-faktor apa saja yang menjadi penyebab hambatan pada pengadaan jasa konsultan secara e-seleksi di Pemerintah Provinsi DKI Jakarta agar meningkatkan keberhasilan dan tidak terjadinya lagi hambatan pada e-seleksi jasa konsultan. Sampel yang digunakan dalam penelitian ini sebanyak 79 sampel terdiri dari pemilik proyek yaitu KPA, PPK, PPTK dan Pokja Unit Kerja Pelayanan Barang/Jasa (UKPBJ) serta dari pihak penyedia jasa yaitu konsultan yang pernah mengikuti eseleksi jasa konsultan di Pemerintah Provinsi DKI Jakarta. Pengambilan sampel penelitian ini dilakukan dengan menggunakan kuesioner dengan teknik nonprobability sampling. Dari data yang telah diperoleh, dilakukan analisis dengan analisis statistik deskriptif untuk mendapatkan variabel yang menjadi faktor-faktor dominan pada pengadaan jasa konsultan. Hasil penelitian ini menemukan bahwa terdapat 25 faktor-faktor yang menjadi hambatan pada pengadaan jasa konsultan secara e-seleksi di Pemerintah Provinsi DKI Jakarta dengan faktor yang paling sering terjadi setelah mendapatkan rekomendasi dari pakar terdapat yaitu ada 7 (tujuh) faktor yang menjadi faktor-faktor dominan yaitu Tenaga Ahli tetap perusahaan (X6), Jumlah Pengalaman perusahaan (X5), Dokumen penawaran tidak lengkap (X11), Spesifikasi teknis kurang dari yang di syaratkan (X13), Kualifikasi personil manajerial untuk pelaksanaan pekerjaan tidak sesuai (X12), jumlah peserta yang lulus kualifikasi kurang dari 3 peserta (X8),dan Kualifikasi personil tim proyek tidak sesuai (X14).
\end{abstract}

Kata Kunci : Hambatan, Pengadaan, e-seleksi, Konsultan, pemerintah, Provinsi, DKI Jakarta

\begin{abstract}
Procurement is an activity related to the fulfillment / provision (goods or services) of a particular project. Procurement of goods / services or better known as auction or selection (procurement) has been carried out by all parties, both from the government and the private sector. Obstacles that occur in the auction can be caused by various factors from related parties (stakeholders), both
\end{abstract}




\begin{abstract}
from budget users, government goods / services procurement service units and from partners who participate in the government procurement process. With the occurrence of many auction failures, it is necessary to analyze what factors affect the obstacles to the auction process conducted electronically in the DKI Jakarta Provincial Government by taking research samples from service users and service providers who are consulting companies that participate in the auction process in Jakarta. activity packages that experience failed auction during the process of procuring goods and services electronically at the Provincial Government of DKI Jakarta. This study aims to identify the factors that cause obstacles to the procurement of consultant services by e-selection in the DKI Jakarta Provincial Government in order to increase success and avoid obstacles to e-selection for consultant services. The sample used in this study was 79 samples consisting of project owners, namely KPA, PPK, PPTK and Working Unit for Goods / Services Work Unit (UKPBJ) as well as from service providers, namely consultants who have participated in e-selection for consultant services in the DKI Jakarta Provincial Government. The research sample was taken by using a questionnaire with a nonprobability sampling technique. From the data that has been obtained, an analysis was carried out with descriptive statistical analysis to obtain the variables which are the dominant factors in the procurement of consultant services. The results of this study found that there are 25 factors that become obstacles to the procurement of consultant services by e-selection in the Provincial Government of DKI Jakarta with the most common factors after getting recommendations from experts, namely there are 7 (seven) factors that are dominant factors. that is The company's permanent experts (X6), Total company experience (X5), Incomplete bidding documents (X11), Technical specifications less than required (X13), Qualifications of managerial personnel for the implementation of work are not appropriate (X12), the number of participants who pass qualifications of less than 3 participants (X8), and Project team personnel qualifications are not appropriate (X14).
\end{abstract}

Keywords: Obstacle, Procurement, e-selection, Consultants, government, province, DKI Jakarta

\section{PENDAHULUAN}

Dengan adanya perkembangan teknologi saat ini telah sangat maju pesat diberbagai bidang, salah satunya dibidang pengadaan barang/jasa dimana demi tercapainya pengadaan yang bersifat terbuka, transparan, efektif dan efisien pada proses pengadaan barang/jasa pun yaitu dilakukan dengan memanfaatkan teknologi informasi dan komunikasi untuk melakukan pengadaan barang/jasa yang kemudian dikenal dengan istilah e-Procurement atau pengadaan barang/jasa secara elektronik. Pelaksanaan E-Procurement telah dilakukan dibanyak Negara salah satunya di Malaysia yang telah dilaksanakan sejak tahun 1999. Indonesia pelaksanaan e-Procurement dimulai sejak dikeluarkannya Keppres nomor 80 tahun 2003 yang mengatur tentang Pengadaan Barang/Jasa Pemerintah dengan harapan dapat mewujudkan Good Governance yang bersifat terbuka, transparan, efektif dan efisien. Namun dalam Pelaksanaan e-Procurement tidaklah mudah. Banyak kendala yang ditemui dalam pelaksanaannya. Contoh yang dapat diambil dalam pelaksanaan e-Procurement di Negara berkembang, ada hambatan dan tantangan dalam implementasi eProcurement antara lain dari aspek teknologi, aspek management, aspek organisasi dan aspek lingkungan (Quangdung, Huang, Liu, \& Ekram, 2011). Daerah Khusus Ibukota Jakarta (DKI Jakarta) yang merupakan ibu kota negara Indonesia adalah pusat perekonomian terbesar se Indonesia, menjadikan kota ini memiliki peran yang sangat strategis. Jakarta sebagai ibukota juga merupakan sebuah tempat proses pengambilan keputusan yang mempengaruhi kehidupan masa depan suatu bangsa serta dapat mempengaruhi trend dan kegiatan di luar perbatasan (wilayahnya). Selain itu, secara ekonomi DKI Jakarta pada level nasional juga memiliki pengaruh yang signifikan. Produk domestik regional bruto (PDRB) DKI Jakarta tahun 2018 diperkirakan sebesar 
Rp. 2.5999 .17 triliun atau $17.5 \%$ dari produk domestik bruto (PDB) nasional (Badan Pusat Statistik, 2018). Selain itu DKI Jakarta juga berupakan provinsi dengan APBD terbesar di Indonesia

E-Procurement sebagai bentuk dari eGovernment dalam proses pengadaan barang jasa mulai berkembang di dunia sejak tahun 2000 dan diterapkan di Indonesia sejak tahun 2008. Potensi manfaat teknologi informasi dan komunikasi yang dinamis dan inovatif mendorong pemerintah di seluruh dunia untuk menerapkan e-Government, termasuk e-Procurement, dalam pelayanan publik (Ndou, 2004 dalam Neupane et al., 2015). Tujuan utama dari penerapan EProcurement adalah mewujudkan clean and good government dalam pengadaan barang jasa. Pengadaan barang jasa diestimasi menyumbang 10-15\% dari PDB negara maju dan $20-70 \%$ PDB negara-negara berkembang (Neupane et al., 2015). Di Indonesia, belanja pengadaan barang jasa nilainya mencapai $11-15 \%$ dari total PDB (LKPP, 2018).

Di Pemerintah Provinsi DKI Jakarta pengadaan barang/jasa pemerintah mulai tahun anggaran 2011 sudah dilakukan secara elektronik. Pada tahun anggaran 2018 terdapat 335 paket pekerjaan konsultan, 427 paket pekerjaan pengadaan barang, 473 paket pekerjaan jasa konstruksi dan 251 paket kegiatan jasa lainnya yang di tenderkan. Dari 335 paket pekerjaan konsultan yang ditenderkan terdapat 55 paket yang dalam proses lelangnya pernah mengalami gagal lelang (Badan Pelayanan Pengadaan Barang Jasa ,2019).

Berikut ini adalah jumlah pengadaan yang dilaksanakan di Badan Pelayanan Pengadaan Barang Jasa Provinsi DKI Jakarta dapat dilihat dari jumlah paket kegiatan yang dilaksanakan dapat dilihat pada gambar 1

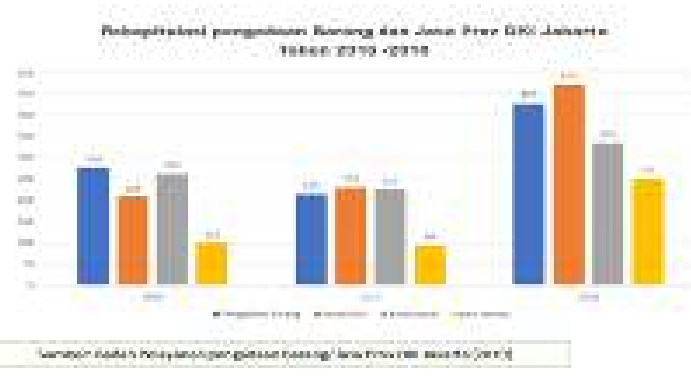

Gambar 1. Grafik RekapitulasiPengadaan Barang dan Jasa Prov, DKI Jakarta

(Sumber: Badan Pelayanan Barang/Jasa Prov DKI Jakarta, 2019)

Berikut ini adalah jumlah pengadaan jasa konsultan yang dilaksanakan dengan metode e-seleksi di Badan Pelayanan Pengadaan Barang Jasa Provinsi DKI Jakarta dapat dilihat pada Gambar 2.

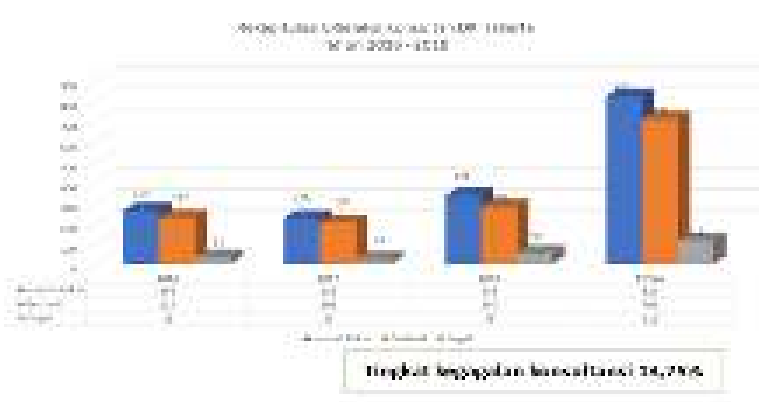

Gambar 2. Grafik Rekapitulasi E-Seleksi Konsultan DKI Jakarta

(Sumber: Badan Pelayanan Barang/Jasa Prov DKI Jakarta, 2019)

Gagalnya lelang merupakan bagian dari suatu hambatan proses pengadaan Jasa Konsultasi bisa disebabkan oleh berbagai faktor dari pihak - pihak terkait (stake holders), baik dari pengguna anggaran, unit layanan pengadaan barang/jasa pemerintah maupun dari pihak rekanan yang mengikuti proses pengadaan barang / jasa pemerintah. Dengan banyak terjadinya kegagalan lelang, maka perlu dilakukan analisis terhadap faktor -faktor apa saja yang mempengaruhi kegagalan proses lelang yang dilakukan secara elektronik di Pemerintah Provinsi DKI Jakarta dengan mengambil sampel penelitian pada perusahaan kontraktor yang 
mengikuti proses lelang pada paket - paket kegiatan yang mengalami gagal lelang selama dilakukannya proses pengadaan barang dan jasa secara elektronik di Pemerintah Provinsi DKI Jakarta.

Berikut ini adalah jumlah pengadaan jasa konsultan yang telah dilakukan re e-seleksi yang dilaksanakan di Badan Pelayanan Pengadaan Barang Jasa Provinsi DKI Jakarta dapat dilihat pada Gambar 3

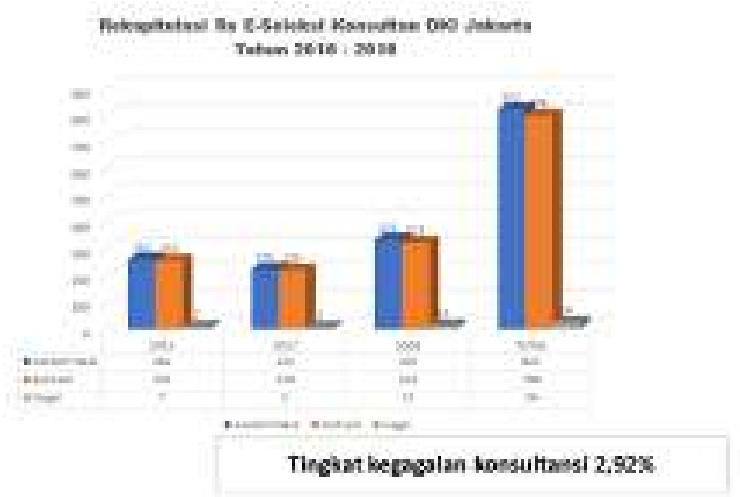

Gambar 3. Grafik Rekapitulasi Gagal Re eSeleksi Konsultan DKI Jakarta

(Sumber: Badan Pelayanan Barang/Jasa Prov DKI Jakarta, 2019)

\section{TINJAUAN PUSTAKA}

Proyek konsultan merupakan suatu rangkaian kegiatan yang saling berkaitan untuk mencapai tujuan tertentu (bangunan/konsultan) dalam batasan waktu, biaya dan mutu tertentu.

Proyek adalah merupakan sekumpulan aktivitas yang saling berhubungan dimana ada titik awal dan titik akhir serta hasil tertentu. Proyek biasanya bersifat lintas fungsi organisasi sehingga membutuhkan berbagai keahlian (skills) dari berbagai profesi dan organisasi. Setiap proyek adalah unik, bahkan tidak ada dua proyek yang persis sama. Proyek adalah aktivitas sementara dari personil, material, serta sarana untuk menjadikan/mewujudkan sasaran-sasaran (goals) proyek dalam kurun waktu tertentu yang kemudian berakhir (PT. PP, 2003).

Rangkaian kegiatan dalam proyek konsultan diawali dengan lahirnya suatu gagasan yang muncul dari adanya kebutuhan dan dilanjutkan dengan penelitian terhadap kemungkinan terwujudnya gagasan tersebut (studi kelayakan).

Selanjutnya dilakukan desain awal (preliminary design), desain rinci (detail design), pengadaan (procurement) sumber daya, pembangunan di lokasi yang telah disediakan (konsultan) dan pemeliharaan bangunan yang telah didirikan (maintenance) sampai dengan penyerahan bangunan kepada pemilik proyek.

Lelang merupakan serangkaian kegiatan untuk menyediakan barang/jasa dengan cara menciptakan persaingan yang sehat diantara penyedia barang/jasa yang setara dan memenuhi syarat, berdasarkan metode dan tata cara tertentu yang telah ditetapkan dan diikuti oleh pihak-pihak yang terkait secara taat asas sehingga terpilih penyedia terbaik. (Ervianto, 2005).

Lelang merupakan salah satu cara bagi pengguna barang dan jasa untuk mencari penyedia barang dan jasa, sedangkan bagi penyedia jasa mengikuti lelang merupakan salah satu cara untuk menjaga agar perusahaan tetap memiliki pekerjaan sehingga adanya arus pemasukan kas, memperoleh laba dan keuntungan, mendapatkan pengalaman dan teknologi baru, menjaga kelangsungan kontak dengan pemilik pekerjaan, subkontraktor, serta mempertahankan ikatan kerja dengan staf dan pekerja yang cakap (Soeharto, 1997).

Peserta diartikan sebagai turut berperan serta dalam suatu kegiatan. Selanjutnya penyedia jasa sebagai peserta didalam lelang diartikan sebagai peran penyedia jasa mulai dari proses pendaftaran untuk ikut lelang, proses pemasukan penawaran, hingga akhirnya penetapan pemenang lelang (proses awal sampai akhir lelang). Penyedia jasa yang hanya berperan serta sampai pada pendaftaran saja tidak dikategorikan sebagai peserta lelang.

Menurut Standar Dokumen Pengadaan (SDP) barang/jasa pemerintah secara elektronik dengan e-tendering yang dimaksud sebagai peserta lelang adalah 
penyedia jasa yang menyampaikan dokumen penawaran yang dapat dibuka dan dapat dievaluasi yang sekurang kurangnya memuat harga penawaran, daftar kuantitas dan harga, jangka waktu penawaran dan spesifikasi barang/bahan yang ditawarkan. Kontraktor sebagai penyedia jasa tentunya memiliki pertimbangan untuk ikut atau tidaknya didalam kegiatan lelang. Pertimbangan tersebut didasarkan pada pengalaman, penilaian dan persepsi masingmasing orang yang berperan dalam proses lelang terhadap faktor-faktor yang dihadapi seperti misalnya kondisi ekonomi, karakteristik proyek yang dilelangkan, dokumen proyek, kondisi lelang, dan karakteristik kontraktor itu sendiri.

Pengadaan barang dimulai sejak adanya pasar dimana orang dapat membeli dan atau menjual barang. Cara atau metoda yang digunakan dalam jual beli barang di pasar adalah dengan cara tawar menawar secara langsung antara pihak pembeli (pengguna) dan pihak penjual (penyedia barang). Pada perkembangan selanjutnya pihak pengguna menyampaikan daftar barang yang akan dibeli tidak hanya kepada satu tetapi ke beberapa penyedia barang. Dengan meminta penawaran kepada beberapa penyedia barang, pengguna dapat memilih harga penawaran yang paling murah dari setiap barang yang akan dibeli. Cara demikian merupakan cikal bakal pengadaan barang secara lelang. Sekarang pengadaan barang tidak terbatas pada barang berwujud tetapi juga pada barang yang tidak berwujud (jasa). Pengadaan barang yang tidak berwujud yang umumnya berupa jasa tersebut merupakan asal usul pengadaan jasa (Luknanto, 2004). Pengadaan barang/jasa Pemerintah yang selanjutnya disebut dengan Pengadaan barang/jasa adalah kegiatan untuk memperoleh barang/jasa oleh Kementerian/Lembaga/Satuan Kerja Perangkat Daerah/Institusi yang prosesnya dimulai dari perencanaan kebutuhan sampai diselesaikannya seluruh kegiatan untuk memperoleh barang/jasa. Jenis pengadaan barang/jasa pemerintah antara lain, pekerjaan konstruksi yaitu seluruh pekerjaan yang berhubungan dengan pelaksanaan konstruksi bangunan atau perbuatan wujud fisik lainnya dan jasa konsultasi yaitu jasa layanan profesional yang membutuhkan keahlian tertentu diberbagai bidang keilmuan yang mengutamakan adanya olah pikir (Pemerintah, 2012).

Pengadaan barang/jasa secara elektronik adalah pengadaan barang/jasa yang dilaksanakan dengan menggunakan teknologi informasi dan transaksi elektronik sesuai dengan ketentuan perundangundangan, yang tata cara pemilihan penyedia barang/jasanya dilakukan dengan tata cara e-tendering yaitu tata cara pemilihan penyedia barang/jasa yang dilakukan secara terbuka dan dapat diikuti oleh semua penyedia barang/jasa yang terdaftar pada sistem pengadaan secara elektronik dengan cara menyampaikan satu kali penawaran dalam waktu yang telah ditentukan (Anonim, 2012).

\section{METODOLOGI PENELITIAN}

Penelitian ini merupakan penelitian explorasi yang meneliti suatu obyek penelitian untuk memahami dan memperoleh pengetahuan tentang faktorfaktor hambatan pada pengadaan Jasa Konsultan secara e-seleksi dari sudut pandang pemerintah. Penelitian ini dilakukan karena peneliti belum mempunyai gambaran mengenai hal yang akan diteliti. Metode yang dipakai untuk mengidentifikasi variabel hambatan dalam pelaksanaan e-seleksi pada Jasa Konsultan secara e-seleksi di Pemerintah Provinsi DKI Jakarta sebagai variabel penelitian adalah melalui studi literatur. Selanjutnya dilakukan uji validitas dan reliabilitas dengan bantuan program SPSS untuk 
mengetahui ketepatan alat ukur yang dipakai. Dari hasil analisis tersebut akan diketahui faktor-faktor penghambat yang paling dominan atau yang kuat pengaruhnya yang kemudian dibuat menjadi kuesioner berupa tanya jawab untuk mengetahui tindakan atau cara untuk meminimalisasi pengaruh faktor-faktor hambatan tersebut.

Variabel penelitian adalah suatu atribut atau sifat atau nilai dari orang, objek, atau kegiatan yang mempunyai variasi tertentu yang ditetapkan oleh peneliti untuk dapat dipelajari dan dapat ditarik suatu kesimpulannya (Sugiyono, 2012). Menurut hubungannya, maka variabel penelitian dapat dibedakan menjadi:

1. Variabel independen atau Variabel bebas: Variabel dikatakan independen apabila variabel tersebut bertindak sebagai variabel pemicu, input, prediktor dan anticendent. Variabel independen disebut juga sebagai variabel bebas atau variabel yang menjadi sebab timbulnya perubahan pada variabel dependen (variabel terikat). Jadi variabel independen adalah variabel yang mempengaruhi.

2. Variabel dependen: Suatu variabel dikatakan dependen apabila variabel tersebut merupakan variabel terikat yang dipengaruhi atau menjadi akibat karena adanya variabel bebas

\section{INSTRUMEN PENELITIAN}

Kualitas data sangat ditentukan oleh alat pengumpul data yang digunakan Oleh karena itu, suatu instrumen harus memiliki persyaratan yang telah ditentukan sebagai berikut (Yin, 2002):

1. Valid atau sah, artinya instrumen tersebut harus menunjukkan sejauh manakah ia mengukur apa yang seharusnya diukur.

2. Reliabel atau ejek, artinya instrumen memiliki daya keterandalan apakah ia lakukan dalam waktu yang lain yang berulang-ulang dalam kondisi yang sama kepada subyek yang sama harus menghasilkan hal yang hampir sama atau bahkan tetap sama

3. Obyektif atau terbuka, artinya penggunaan instrumen (alat) pengumpul data, tidak mempengaruhi pengumpulannya (orang) dan objeknya (yang diteliti). Terdapat empat kategori tingkat pengukuran suatu data pengamatan yaitu:

\section{a. Ukuran Nominal}

Ukuran nominal adalah tingkat pengukuran yang paling sederhana. Pada ukuran ini tidak terdapat asumsi tentang jarak maupun urutan antara kategori- kategori dalam ukuran itu. Dasar penggolongan pada ukuran nominal hanyalah kategori yang tidak tumpang tindih dan tuntas.

b. Ukuran Ordinal

Merupakan pengukuran yang didasarkan pada jenjang dalam suatu atribut tertentu

\section{c. Ukuran Interval}

Ukuran interval adalah ukuran yang mengurutkan orang atau objek berdasarkan atribut tertentu, dan memberikan informasi tentang interval antara satu orang atau objek dengan orang atau objek lainnya.

d. Ukuran Rasio

Ukuran rasio adalah suatu ukuran yang berbentuk interval yang jaraknya tidak dinyatakan sebagai perbedaan nilai antar responden, tetapi antara seorang responden dengan nilai nol absolut.

Instrumen penelitian yang digunakan adalah kuesioner. Kuesioner dibuat untuk memperoleh data primer yang disusun berdasarkan parameter-parameter analisis yang dibutuhkan dan relevan sesuai dengan maksud dan tujuan dari penelitian ini. Kuesioner ini akan diberikan kepada responden-responden yang representatif dari tujuan penelitian, yaitu Kelompok kerja Unit Kerja Pelayanan Pengadaan Barang dan Jasa (Pokja UKPBJ) Provinsi DKI Jakarta, PPK, PPTK dan Penyedia Jasa Konsultan di lingkungan Pemerintah Provinsi DKI Jakarta. Instrumen penelitian ini berupa kuesioner, yang disusun dengan tahapan pelaksanaan sebagai berikut : 
1. Pernyataan-pernyataan yang merupakan hasil transformasi dari suatu indikator dari variabel penelitian tersebut disusun dalam bentuk format tabulasi.

2. Pernyataan dalam bentuk kuesioner tersebut selanjutnya dimintakan klarifikasi dan validasi kepada para pakar.

3. Berdasarkan masukan dan pendapat dari beberapa pakar tersebut ditransformasikan menjadi pernyataan yang dituangkan dalam bentuk kuesioner.

4. Kuesioner tersebut dipergunakan sebagai instrumen pengumpulan data, yang didistribusikan kepada responden yang dapat mewakili populasi.

\section{Populasi dan sampel}

Populasi adalah keseluruhan elemen atau unsur yang akan diteliti, sedangkan sampel merupakan sebagian dari populasi. Syarat suatu sampel yang baik adalah sampel tersebut dapat mewakili sebanyak mungkin karakteristik populasi.

Berikut adalah penjabaran populasi dan sampel untuk masing-masing rumusan masalah:

1. RQ1: Faktor apa saja yang menyebabkan terjadinya gagal tender pada proses pengadaan barang/jasa secara elektronik (e-tendering)?

Untuk menjawab RQ 1, dalam survey kuesioner populasi yang di gunakan adalah para pakar praktisi pengadaan barang/jasa pemerintah. Metode sampling adalah nonrandom expert sampling, yaitu metode pemilihan sampel non-acak dengan responden yang dipercaya penulis sebagai seseorang yang memiliki syarat keahlian yang dibutuhkan dalam penelitian (Kumar, 2011). Jumlah sampel rencana pada tahap ini adalah 5 responden. Untuk menjawab RQ1 juga digunakan servey kuesioner dengan populasi yang di gunakan adalah pihak - pihak yang melakukan e-seleksi jasa konsultan di Pemerintah Provinsi DKI
Jakarta yaitu Pokja UKPBJ Provinsi DKI Jakarta, PPK/PPTK, dan Penyedia Jasa Konstruksi. Untuk analisis statistik, jumlah sampel minimum yang dibutuhkan adalah 50 responden

2. RQ2: Siapa pihak-pihak yang terlibat dan perannya dalam pelaksanaan etendering?

Untuk menjawab RQ 2, dalam survey kuesioner populasi yang di gunakan adalah para pakar praktisi pengadaan barang/jasa pemerintah. Metode sampling adalah nonrandom expert sampling, yaitu metode pemilihan sampel non-acak dengan responden yang dipercaya penulis sebagai seseorang yang memiliki syarat keahlian yang dibutuhkan dalam penelitian (Kumar, 2011). Jumlah sampel rencana pada tahap ini adalah 50 responden.

3. RQ3: Bagaimana strategi meningkatkan keberhasilan tender dengan menggunakan e-tendering?

Untuk menjawab RQ 3, dalam survey kuesioner populasi yang di gunakan adalah para pakar praktisi pengadaan barang/jasa pemerintah. Metode sampling adalah nonrandom expert sampling, yaitu metode pemilihan sampel non-acak dengan responden yang dipercaya penulis sebagai seseorang yang memiliki syarat keahlian yang dibutuhkan dalam penelitian (Kumar, 2011).

\section{ANALISIS DAN PEMBAHASAN}

Data yang didapat pada penelitian ini dengan menggunakan cara menyebarkan kuesioner melalui 3 tahap. Adapun tahapan dalam pengumpulan data dapat dijelaskan pada tahap ini akan dilakukan validasi variabel penelitian diperoleh dari 5 orang pakar yang telah memiliki sertifikat pengadaan barang jasa dan atau sertifikat kompetensi barang jasa (sertifikat fungsional) serta memiliki pengalaman lebih dari 10 tahun dalam pengadaan barang dan jasa pemerintah. 
Tabel 1. Data Umum Pakar

\begin{tabular}{|c|c|c|l|c|}
\hline N & Pak & $\begin{array}{c}\text { Pendidik } \\
\text { an } \\
\text { terakhir }\end{array}$ & Jabatan & $\begin{array}{c}\text { Pengala } \\
\text { man } \\
\text { pengadaa } \\
\text { n barang } \\
\text { / jasa }\end{array}$ \\
\hline 1 & $\begin{array}{c}\text { Paka } \\
\text { r 1 }\end{array}$ & S2 & $\begin{array}{l}\text { Kasubbid } \\
\text { Perencan } \\
\text { aan } \\
\text { Pengadaa } \\
\text { n }\end{array}$ & 15 tahun \\
\hline 2 & $\begin{array}{c}\text { Paka } \\
\text { r 2 }\end{array}$ & S2 & $\begin{array}{l}\text { Kasubbid } \\
\text { Pengelola } \\
\text { an }\end{array}$ & 15 tahun \\
\hline 3 & $\begin{array}{c}\text { Paka } \\
\text { r 3 }\end{array}$ & S2 & $\begin{array}{l}\text { Fungsion } \\
\text { al } \\
\text { Pengadaa } \\
\text { n Muda }\end{array}$ & 15 tahun \\
\hline 5 & $\begin{array}{c}\text { Paka } \\
\text { r 5 }\end{array}$ & S1 & $\begin{array}{l}\text { Fungsion } \\
\text { al } \\
\text { Pengadaa } \\
\text { n Muda }\end{array}$ & $\begin{array}{l}\text { Fungsion } \\
\text { al } \\
\text { Pengadaa } \\
\text { n Muda }\end{array}$ \\
\hline
\end{tabular}

Penelitian ini berdasarkan pendapat dari responden yang terkumpul sebanyak 79 responden yang terdiri dari 9 Pengguna Jasa, 43 Pokja Pemilihan dan 27 penyedia jasa konsultan dalam berbagai klasifikasi usia, jenis kelamin, pengalaman kerja di bidang pengadaan barang dan jasa dan kepemilikan sertifikat, seperti pada tabel 2 berikut ini
Tabel 2. Perbandingan Jumlah Responden

\begin{tabular}{|c|c|c|c|c|}
\hline $\begin{array}{c}\text { Klasifikasi } \\
\text { Berdasark } \\
\text { an }\end{array}$ & $\begin{array}{c}\text { Kelompo } \\
\text { k } \\
\text { Respond } \\
\text { en }\end{array}$ & $\begin{array}{l}\text { Peng } \\
\text { guna } \\
\text { Jasa } \\
\text { (PA/ } \\
\text { KPA/ } \\
\text { PPK) }\end{array}$ & $\begin{array}{l}\text { Pokj } \\
\quad a \\
\text { Pemi } \\
\text { lihan }\end{array}$ & $\begin{array}{l}\text { Penye } \\
\text { dia } \\
\text { Jasa } \\
\text { (Kons } \\
\text { ultan) }\end{array}$ \\
\hline Usia & $\begin{array}{l}20-30 \\
31-40 \\
41-50 \\
>50\end{array}$ & $\begin{array}{l}- \\
4 \\
4 \\
1\end{array}$ & $\begin{array}{c}2 \\
12 \\
21 \\
8\end{array}$ & $\begin{array}{c}6 \\
14 \\
3 \\
4\end{array}$ \\
\hline $\begin{array}{l}\text { Jenis } \\
\text { Kelamin }\end{array}$ & $\begin{array}{l}\text { Laki - } \\
\text { laki } \\
\text { Perempu } \\
\text { an }\end{array}$ & $\begin{array}{l}7 \\
2\end{array}$ & $\begin{array}{l}33 \\
10\end{array}$ & $\begin{array}{c}23 \\
4\end{array}$ \\
\hline $\begin{array}{l}\text { Pengalama } \\
\text { n Kerja } \\
\text { pada } \\
\text { Pengadaan } \\
\text { Barang/ } \\
\text { Jasa }\end{array}$ & $\begin{array}{l}0-10 \\
11-20 \\
>20\end{array}$ & $\begin{array}{l}7 \\
1 \\
1\end{array}$ & $\begin{array}{c}2 \\
30 \\
11\end{array}$ & $\begin{array}{c}21 \\
5 \\
1\end{array}$ \\
\hline $\begin{array}{l}\text { Kepemilik } \\
\text { an } \\
\text { Sertifikat } \\
\text { Pengadaan } \\
\text { Barang/ } \\
\text { Jasa }\end{array}$ & $\begin{array}{l}\text { Memiliki } \\
\text { Sertifikat } \\
\text { Tidak } \\
\text { Memiliki } \\
\text { sertifikat }\end{array}$ & 9 & 43 & 15 \\
\hline
\end{tabular}

Tabel 3. Rekapitulasi Responden

\begin{tabular}{|l|l|}
\hline Kode & Variabel \\
\hline XI & $\begin{array}{l}\text { Setelah pemberian waktu } \\
\text { perpanjangan, tidak ada peserta } \\
\text { yang menyampaikan dokumen } \\
\text { kualifikasi }\end{array}$ \\
\hline X1.1 & Durasi Proyek yang pendek \\
\hline X1.2 & $\begin{array}{l}\text { Persyaratan Prakualifikasi yang } \\
\text { kompleks }\end{array}$ \\
\hline X1.3 & $\begin{array}{l}\text { Proyek mendapat pertentangan } \\
\text { dari masyarakat }\end{array}$ \\
\hline X1.4 & Lahan belum bebas \\
\hline
\end{tabular}




\begin{tabular}{|c|c|}
\hline Kode & Variabel \\
\hline $\mathrm{X} 1.5$ & Jumlah Pengalaman perusahaan \\
\hline $\mathrm{X} 1.6$ & Tenaga Ahli tetap perusahaan \\
\hline $\mathrm{X} 2$ & $\begin{array}{l}\text { Dalam proses evaluasi dokumen } \\
\text { kualifikasi }\end{array}$ \\
\hline $\mathrm{X} 2.1$ & $\begin{array}{l}\text { Tidak mencapai nilai ambang batas } \\
\text { yang dipersyaratkan }\end{array}$ \\
\hline $\mathrm{X} 2.2$ & $\begin{array}{l}\text { Jumlah Peserta yang lulus } \\
\text { kualifikasi kurang dari } 3 \text { peserta }\end{array}$ \\
\hline $\mathrm{X} 2.3$ & $\begin{array}{l}\text { Sanggahan peserta terhadap } \\
\text { pelaksanaan tender dan dokumen } \\
\text { pengadaan ternyata benar }\end{array}$ \\
\hline $\mathrm{X} 3$ & $\begin{array}{l}\text { Dalam proses evaluasi dokumen } \\
\text { pemilihan }\end{array}$ \\
\hline X3.1 & $\begin{array}{l}\text { Surat Penawaran tidak sesuai } \\
\text { dengan dokumen pemilihan }\end{array}$ \\
\hline $\mathrm{X} 3.2$ & $\begin{array}{lll}\text { Dokumen penawaran } & \text { tidak } \\
\text { lengkap } & & \end{array}$ \\
\hline X3.3 & $\begin{array}{l}\text { Kualifikasi personil manajerial } \\
\text { untuk pelaksanaan pekerjaan tidak } \\
\text { sesuai }\end{array}$ \\
\hline X3.4 & $\begin{array}{l}\text { Spesifikasi teknis kurang dari yang } \\
\text { di syaratkan }\end{array}$ \\
\hline X3.5 & $\begin{array}{l}\text { Kualifikasi Personil tim proyek } \\
\text { tidak sesuai }\end{array}$ \\
\hline $\mathrm{X} 4$ & $\begin{array}{l}\text { Seluruh penawaran setelah koreksi } \\
\text { lebih tinggi dari HPS }\end{array}$ \\
\hline $\mathrm{X} 4.1$ & $\begin{array}{l}\text { Besarnya biaya overhead proyek } \\
\text { yang dimasukkan ke dalam biaya } \\
\text { penawaran }\end{array}$ \\
\hline $\mathrm{X} 4.2$ & Kesalahan dalam survey harga \\
\hline $\mathrm{X} 4.3$ & $\begin{array}{l}\text { Estimator yang } \\
\text { berpengalaman }\end{array}$ \\
\hline $\mathrm{X} 4.4$ & $\begin{array}{l}\text { Dokumen tender yang tidak } \\
\text { lengkap/tidak jelas }\end{array}$ \\
\hline $\mathrm{X} 4.5$ & Fluktuasi nilai tukar mata uang \\
\hline
\end{tabular}

\begin{tabular}{|c|c|}
\hline Kode & Variabel \\
\hline $\mathrm{X} 5$ & $\begin{array}{l}\text { Calon Pemenang dan calon } \\
\text { pemenang cadangan tidak hadir } \\
\text { dalam klarifikasi dan pembuktian } \\
\text { kualifikasi }\end{array}$ \\
\hline $\mathrm{X} 5.1$ & $\begin{array}{l}\text { Tidak siap dengan bukti kualifikasi } \\
\text { yang dimiliki }\end{array}$ \\
\hline $\mathrm{X} 5.2$ & Nilai penawaran terlalu rendah \\
\hline $\mathrm{X} 6$ & $\begin{array}{l}\text { Tidak ada peserta yang } \\
\text { menyampaikan dokumen } \\
\text { penawaran setelah ada pemberian } \\
\text { waktu perpanjangan }\end{array}$ \\
\hline X6.1 & $\begin{array}{l}\text { Kurangnya waktu yang disediakan } \\
\text { untuk mempersiapkan dokumen }\end{array}$ \\
\hline X6.2 & $\begin{array}{l}\text { Perpanjangan surat-surat } \\
\text { administrasi perusahaan belum } \\
\text { selesai (SBU, IUJK, SKA/ SKT,SPT) }\end{array}$ \\
\hline X6.3 & Peserta tidak dapat login di LPSE \\
\hline $\mathrm{X} 7$ & $\begin{array}{l}\text { Dalam dokumen kualifikasi dan } \\
\text { dokumen pemilihan ditemukan } \\
\text { kesalahan atau tidak sesuai dengan } \\
\text { ketentuan peraturan perundang- } \\
\text { undangan terkait pengadaan } \\
\text { barang/jasa pemerintah dan/atau } \\
\text { Peraturan Menteri }\end{array}$ \\
\hline $\mathrm{X} 7.1$ & $\begin{array}{l}\text { Kurangnya pengetahuan PPK } \\
\text { mengenai pengadaan barang/jasa } \\
\text { Pemerintah }\end{array}$ \\
\hline
\end{tabular}

\section{Analisis data}

Validitas adalah ketepatan atau kecermatan suatu instrumen dalam mengukur apa yang ingin diukur, dalam penentuan layak atau tidaknya suatu item yang akan digunakan, pada penelitian ini dilakukan uji signifikansi koefisien korelasi pada tahap signifikansi 0,05 , dimana artinya setiap variabel penelitian dianggap valid jika berkorelasi signifikan terhadap skor total. Sedangkan uji reliabilitas digunakan untuk mengetahui 
konsistensi alat ukur, apakah alat pengukur yang digunakan pada penelitian ini dapat diandalkan dan tetap konsisten jika pengukuran tersebut diulang. Pengujian validitas data yang dilakukan menggunakan corrected item-total correlation yang menggunakan nilai $r$ dari tabel. Sedangkan untuk pengujian reliabilitas menggunakan metoda metode Cronbach's Alpha, dimana variabel penelitian dapat dikatakan reliable jika nilai alpha lebih besar dari $r$ kritis product Moment yang dihasilkan.

Berikut ini adalah hasil output uji validitas dengan menggunakan program SPSS

\section{Uji validitas}

Tabel 4. Hasil Uji Validitas

\begin{tabular}{|c|c|c|c|c|c|c|c|c|}
\hline \multicolumn{9}{|c|}{ Correlations } \\
\hline & & $\begin{array}{c}\mathrm{T} \\
\mathrm{o} \\
\mathrm{t} \\
\mathrm{al}\end{array}$ & & & $\begin{array}{l}\mathrm{T} \\
\mathrm{o} \\
\mathrm{t} \\
\mathrm{a} \\
\mathrm{l}\end{array}$ & & & $\begin{array}{l}\mathrm{T} \\
\text { ot } \\
\text { al }\end{array}$ \\
\hline \multirow[t]{3}{*}{$\begin{array}{c}X \\
0 \\
1\end{array}$} & $\begin{array}{l}\text { Pe } \\
\text { ars } \\
\text { on } \\
\text { Cor } \\
\text { rel } \\
\text { ati } \\
\text { on }\end{array}$ & $\begin{array}{r}5 \\
6 \\
5 \\
* *\end{array}$ & $\begin{array}{l}X \\
1 \\
0\end{array}$ & $\begin{array}{l}\text { Pea } \\
\text { rso } \\
\mathrm{n} \\
\text { Cor } \\
\text { rela } \\
\text { tio } \\
\mathrm{n}\end{array}$ & $\begin{array}{l}\text {, } \\
6 \\
1 \\
8 \\
* *\end{array}$ & $\begin{array}{l}X \\
1 \\
9\end{array}$ & $\begin{array}{l}\text { Pe } \\
\text { ar } \\
\text { so } \\
\mathrm{n} \\
\text { Co } \\
\text { rr } \\
\text { el } \\
\text { ati } \\
\text { on }\end{array}$ & $\begin{array}{r}6 \\
9 \\
6 * \\
*\end{array}$ \\
\hline & $\begin{array}{l}\text { Sig. } \\
(2- \\
\text { tail } \\
\text { ed) }\end{array}$ & $\begin{array}{r}, 0 \\
0 \\
0\end{array}$ & & $\begin{array}{l}\text { Sig. } \\
(2- \\
\text { tail } \\
\text { ed) }\end{array}$ & $\begin{array}{l}{ }^{\prime} \\
0 \\
0\end{array}$ & & $\begin{array}{l}\text { Si } \\
\text { g. } \\
(2 \\
- \\
\text { tai } \\
\text { le } \\
\text { d) }\end{array}$ & $\begin{array}{r}0 \\
0 \\
0\end{array}$ \\
\hline & $\mathrm{N}$ & $\begin{array}{l}7 \\
9\end{array}$ & & $\mathrm{~N}$ & $\begin{array}{l}7 \\
9\end{array}$ & & $\mathrm{~N}$ & $\begin{array}{l}7 \\
9\end{array}$ \\
\hline $\begin{array}{l}X \\
0 \\
2\end{array}$ & $\begin{array}{l}\text { Pe } \\
\text { ars } \\
\text { on } \\
\text { Cor } \\
\text { rel } \\
\text { ati } \\
\text { on }\end{array}$ & $\begin{array}{r}, 5 \\
6 \\
4 \\
* *\end{array}$ & $\begin{array}{l}X \\
1 \\
1\end{array}$ & $\begin{array}{l}\text { Pea } \\
\text { rso } \\
\text { n } \\
\text { Cor } \\
\text { rela } \\
\text { tio } \\
\text { n }\end{array}$ & $\begin{array}{l}\text { ' } \\
5 \\
9 \\
7 \\
\text { ** }\end{array}$ & $\begin{array}{l}X \\
2 \\
0\end{array}$ & $\begin{array}{l}\mathrm{Pe} \\
\text { ar } \\
\text { so } \\
\mathrm{n} \\
\mathrm{Co} \\
\mathrm{rr} \\
\mathrm{el}\end{array}$ & $\begin{array}{r}6 \\
8 \\
4^{*} \\
*\end{array}$ \\
\hline
\end{tabular}

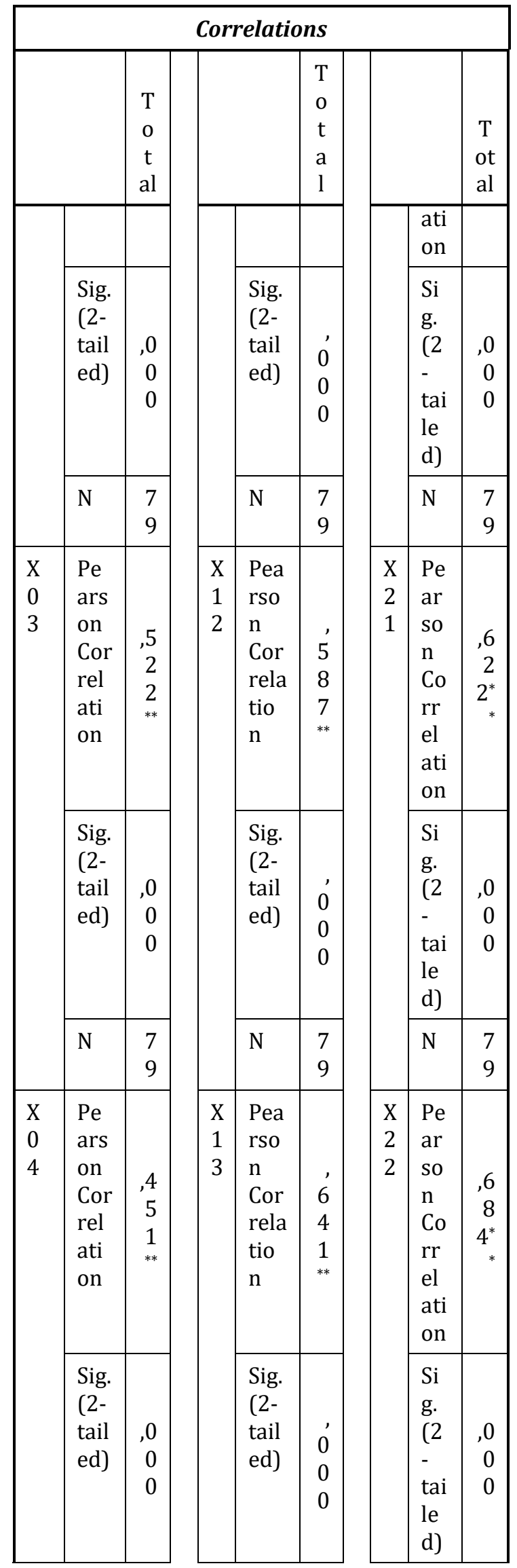




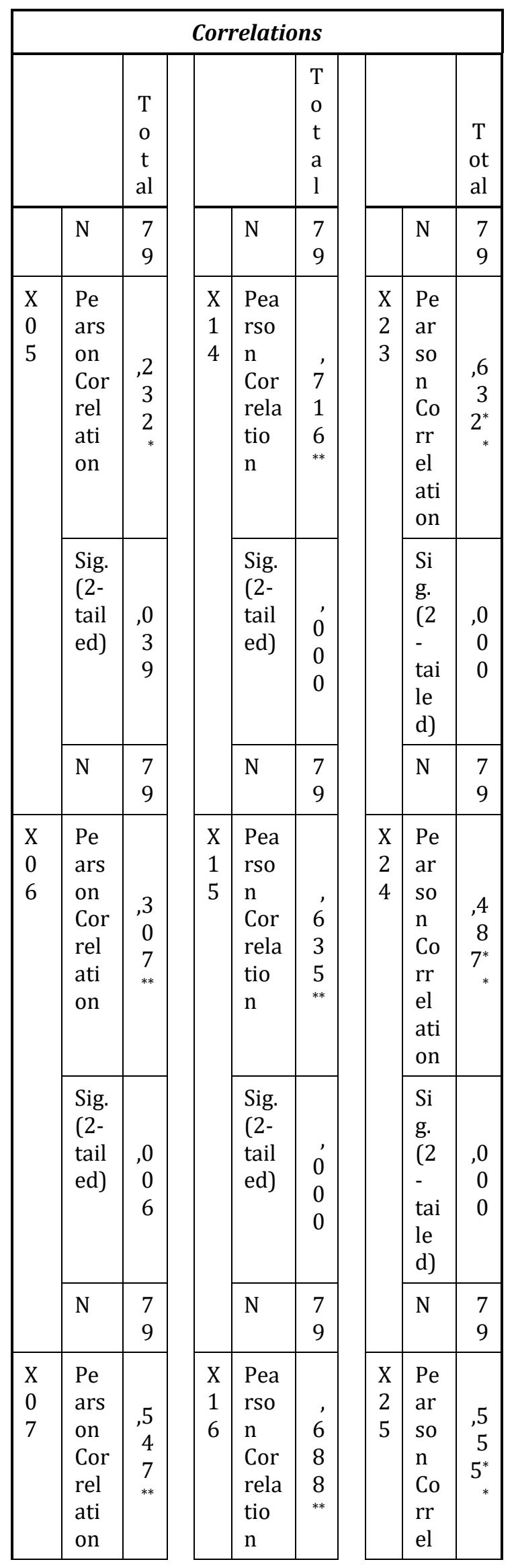

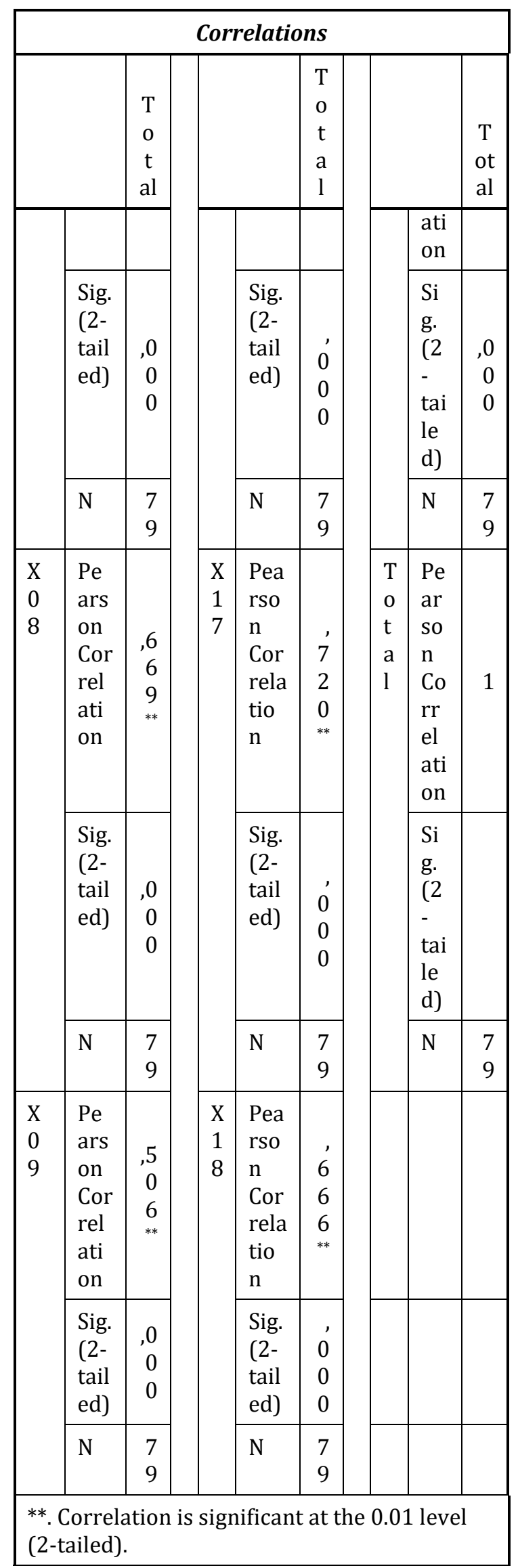




\begin{tabular}{|c|c|c|c|}
\hline \multicolumn{4}{|c|}{ Correlations } \\
\hline & $\begin{array}{c}\mathrm{T} \\
\mathrm{o} \\
\mathrm{t} \\
\mathrm{al}\end{array}$ & $\begin{array}{l}\mathrm{T} \\
\mathrm{o} \\
\mathrm{t} \\
\mathrm{a} \\
\mathrm{l}\end{array}$ & $\begin{array}{l}\mathrm{T} \\
\text { ot } \\
\text { al }\end{array}$ \\
\hline \multicolumn{4}{|c|}{$\begin{array}{l}\text { *. Correlation is significant at the } 0.05 \text { level ( } 2 \text { - } \\
\text { tailed). }\end{array}$} \\
\hline
\end{tabular}

Selanjutnya untuk hasil validasi variabel dapat diuji dengan membandingkan Corrected Item-Total Correlation dengan $r$ tabel. $\mathrm{R}$ tabel pada $\alpha$ 0,05 dengan derajat bebas $\mathrm{df}=(\mathrm{N}-2)$, pada penelitian ini jumlah responden $\mathrm{N}=79$ menjadi $\mathrm{df}=77 . \mathrm{R}$ $(0,05 ; 77)$ pada uji satu arah $=0,2213$.

Pengambilan Keputusan

- Jika $r$ hitung positif dan $r$ hitung > r tabel, maka variabel tersebut valid

- Jika $r$ hitung negatif atau $r$ hitung $<r$ tabel, maka variabel tersebut tidak valid

Nilai R hitung dapat dilihat pada kolom Corrected Item-Total Correlation.

Dari hasil yang didapatkan semua variabel dinyatakan valid.

\section{Uji reliabilitas}

Uji reliabilitas dilakukan dengan membandingkan nilai $r$ Alpha (Alpha Cronbach) dengan nilai $r$ tabel. Jika nilai $r$ Alpha positif dan $>\mathrm{r}$ tabel, maka dapat disimpulkan variabel yang digunakan reliabel. Hasil uji reliabilitas dengan menggunakan Program SPSS dapat dilihat pada tabel berikut:

Tabel 5. Hasil Uji Reliabilitas

\begin{tabular}{|r|r|}
\hline \multicolumn{2}{|c|}{ Reliability Statistics } \\
\hline Cronbach's Alpha & N of Items \\
\hline, 918 & 25 \\
\hline
\end{tabular}

Dari hasil yang didapatkan semua nilai Cronbach's Alpha > 0.60, maka dapat diambil kesimpulan bahwa variabel penelitian ini reliabel.

\section{Uji normalitas residual}

Uji normalitas bertujuan untuk menguji apakah distribusi responden terdistrubusi normal. Uji normalitas dilakukan menggunakan Kolmogorov-Smirnov.

Program SPSS dapat dilihat pada tabel berikut:

Tabel 6. Hasil Uji Normalitas Residual

\begin{tabular}{|l|l|r|}
\hline \multicolumn{2}{|l|}{ One-Sample Kolmogorov-Smirnov Test } \\
\hline \multicolumn{2}{|l|}{} & $\begin{array}{c}\text { Unstandardize } \\
\text { d Residual }\end{array}$ \\
\hline $\mathrm{N}$ & Mean \\
\hline $\begin{array}{l}\text { Normal } \\
\text { Parameters } \\
\text {, }\end{array}$ & $\begin{array}{l}\text { Std. } \\
\text { Deviatio } \\
\mathrm{n}\end{array}$ &, 0000000 \\
\hline $\begin{array}{l}\text { Most } \\
\text { Extreme } \\
\text { Differences }\end{array}$ & Absolute &, 051 \\
\cline { 2 - 3 } & Positive \\
\cline { 2 - 3 } & Negative \\
\hline Kolmogorov-Smirnov Z &, 038 \\
\hline Asymp. Sig. (2-tailed) &, 051 \\
\hline \multicolumn{2}{|l|}{ a. Test distribution is Normal. } \\
\hline b. Calculated from data. \\
\hline
\end{tabular}

\begin{tabular}{|c|c|c|c|}
\hline \multicolumn{4}{|c|}{ Case Processing Summary } \\
\hline & & $\mathrm{N}$ & $\%$ \\
\hline \multirow[t]{3}{*}{ Cases } & Valid & 79 & 100,0 \\
\hline & Excludeda & 0 & 0,0 \\
\hline & Total & 79 & 100,0 \\
\hline \multicolumn{4}{|c|}{$\begin{array}{l}\text { a. Listwise deletion based on all } \\
\text { variables in the procedure. }\end{array}$} \\
\hline
\end{tabular}

Dari tabel diatas dapat disimpulkan nilai Kolmogorov-Smirnov adalah 0,454 dengan tingkat signifikasi jauh di atas 0,05 ; yaitu 
0,986 maka nilai residual berdistribusi normal

\section{Analisis komparatif untuk kategori pengalaman kerja}

Uji Kruskal-Wallis dilakukan untuk menguji perbedaan jawaban responden dengan latar belakang perbedaan pengalaman dalam pengadaan barang/jasa. Adapun perbedaan pengalaman ini dikelompokkan kedalam 3 bagian, seperti yang dapat dilihat pada gambar berikut ini :

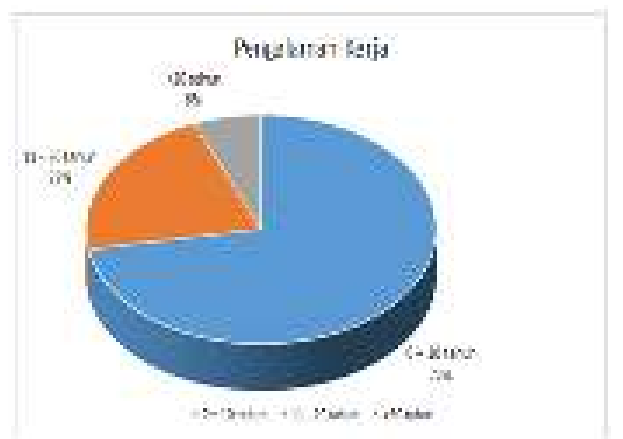

Gambar 4. Sebaran Pengalaman Responden

Gambar 4 menunjukkan bahwa sebagian besar responden adalah Owner (KPA, PPK, PPTK dan Pokja Pemilihan). Selanjutnya, data 79 sampel independen dianalisis dengan program SPSS, dengan hipotesis yang diusulkan sebagai berikut $: \mathrm{Ho}=$ Tidak ada perbedaan persepsi pada responden yang berbeda pada Stakeholder.

$\mathrm{Ha}=$ Ada perbedaan minimal satu persepsi responden yang berbeda pada stakeholder.

Ho diterima jika nilai p-value pada kolom Asymptotic Significant (2-tailed) >

level of significant $(\alpha)$ sebesar 0,05

Ho ditolak jika nilai p-value pada kolom Asymptotic Significant (2-tailed) <

level of significant $(\alpha)$ sebesar 0,05

Setelah melakukan beberapa langkah operasional, maka output yang dihasilkan dari analisis komparatif ini dapat dilihat pada tabel 7 berikut:
Tabel 7. Hasil analisis komparatif pengaruh pengalaman kerja terhadap persepsi responden

\begin{tabular}{|l|l|c|c|c|}
\hline \multicolumn{5}{|c|}{ Ranks } \\
\hline \multirow{4}{|c|}{ Stakeholder } & N & $\begin{array}{c}\text { Mean } \\
\text { Rank }\end{array}$ & $\begin{array}{c}\text { Sum of } \\
\text { Ranks }\end{array}$ \\
\hline Total & $\begin{array}{l}\text { Pengguna } \\
\text { Jasa }\end{array}$ & 53 & 38,05 & 2016,50 \\
\cline { 2 - 5 } & $\begin{array}{l}\text { Penyedia } \\
\text { Jasa }\end{array}$ & 26 & 43,98 & 1143,50 \\
\cline { 2 - 5 } & Total & 79 & & \\
\hline
\end{tabular}

\begin{tabular}{|l|r|}
\hline \multicolumn{2}{|c|}{ Test Statistics $^{\mathbf{a}}$} \\
\hline & \multicolumn{1}{|c|}{ Total } \\
\hline $\begin{array}{l}\text { Mann-Whitney } \\
\text { U }\end{array}$ & 585,500 \\
\hline Wilcoxon W & 2016,500 \\
\hline Z & $-1,080$ \\
\hline $\begin{array}{l}\text { Asymp. Sig. (2- } \\
\text { tailed) }\end{array}$ \\
\hline \multicolumn{2}{|l|}{ a. Grouping Variable: Stakeholder } \\
\hline
\end{tabular}

Diperoleh hasil untuk Kruskall Wallis dengan Program SPPS, diketahui nilai mean rank menunjukkan peringkat rata-rata masing-masing pengalaman. Dalam pembagian berdasarkan pengalaman diatas, peringkat rata-rata pengalaman $>20$ tahun memiliki nilai tertinggi dan peringkat ratarata pengalaman 11 - 20 tahun memiliki nilai terendah. Dari output tersebut juga dapat diketahui bahwa semua variabel mempunyai nilai Asymptotic Significant (2tailed) yang lebih besar dari level of significant $(\alpha)$ 0,05. Jadi Hipotesis nol (Ho) diterima dan $\mathrm{Ha}$ ditolak untuk semua variabel. Dengan demikian dapat diambil kesimpulan bahwa tidak ada perbedaan persepsi responden yang berbeda berdasarkan pengalaman kerja dalam pengadaan barang/ jasa. 


\section{Analisis statistik deskriptif}

Analisis statistik deskriptif bertujuan untuk mendapatkan nilai mean dari keseluruhan penilaian yang telah diberikan oleh para responden atas variabel yang ditanyakan. Hasil dari analisis ini dapat dilihat pada tabel berikut:

Tabel 8. Hasil Hasil Analisis Statistik Deskriptif

\begin{tabular}{|c|c|c|c|c|}
\hline \multicolumn{5}{|c|}{ Descriptive Statistics } \\
\hline & $\mathrm{N}$ & Min & $\operatorname{Max}$ & Mean \\
\hline X06 & 79 & 1 & 5 & 3,42 \\
\hline X05 & 79 & 1 & 5 & 3,34 \\
\hline X11 & 79 & 1 & 5 & 3,10 \\
\hline $\mathrm{X} 13$ & 79 & 1 & 5 & 3,06 \\
\hline $\mathrm{X} 12$ & 79 & 1 & 5 & 3,05 \\
\hline X08 & 79 & 1 & 5 & 3,05 \\
\hline $\mathrm{X} 14$ & 79 & 1 & 5 & 3,01 \\
\hline X07 & 79 & 1 & 5 & 2,95 \\
\hline X16 & 79 & 1 & 5 & 2,84 \\
\hline X02 & 79 & 1 & 5 & 2,80 \\
\hline $\mathrm{X} 25$ & 79 & 1 & 5 & 2,80 \\
\hline $\mathrm{X} 17$ & 79 & 1 & 5 & 2,76 \\
\hline $\mathrm{X} 23$ & 79 & 1 & 5 & 2,75 \\
\hline X01 & 79 & 1 & 5 & 2,73 \\
\hline $\mathrm{X} 21$ & 79 & 1 & 5 & 2,72 \\
\hline X18 & 79 & 1 & 5 & 2,72 \\
\hline $\mathrm{X} 22$ & 79 & 1 & 5 & 2,62 \\
\hline X15 & 79 & 1 & 5 & 2,54 \\
\hline X20 & 79 & 1 & 5 & 2,52 \\
\hline $\mathrm{X} 10$ & 79 & 1 & 5 & 2,43 \\
\hline X24 & 79 & 1 & 5 & 2,41 \\
\hline X19 & 79 & 1 & 5 & 2,27 \\
\hline X04 & 79 & 1 & 5 & 2,16 \\
\hline X09 & 79 & 1 & 4 & 2,16 \\
\hline X03 & 79 & 1 & 5 & 2,15 \\
\hline $\begin{array}{l}\text { Valid N } \\
\text { (listwis } \\
\text { e) }\end{array}$ & 79 & & & \\
\hline
\end{tabular}

Dari tabel diatas didapatkan variabel faktorfaktor menjadi hambatan pada pengadaan jasa konsultan secara e-seleksi dari yang paling sering terjadi hingga yang paling jarang terjadi.

\section{Hasil pembahasan}

Berdasarkan hasil output uji normalitas, semua nilai signifikansi Uji KolmogorovSmirnov Significant pada setiap variabel diatas angka 0,05. Artinya data yang diperoleh merupakan data yang distribusi normal dan analisis statistik yang digunakan adalah analisis statistik non parametrik. Selanjutnya untuk hasil validasi variabel dapat diuji dengan cara membandingkan nilai Corrected Item-Total Correlation dengan nilai $r$ tabel. Dalam uji validitas menunjukkan semua variabel valid

Selanjutnya uji reliabilitas dilakukan dengan membandingkan $r$ Alpha (Alpha Cronbach) dengan $r$ tabel. Jika nilai $r$ Alpha positif dan $>$ r tabel, maka dapat dikatakan reliabel. Dari hasil yang didapatkan semua nilai Cronbach's Alpha > 0.918, maka dapat diambil kesimpulan bahwa variabel penelitian ini reliabel. sehingga respon jawaban dari responden akan bervariasi karena masing-masing mempunyai opini yang berbeda, bukan karena kuesioner yang membingungkan dan multi interpretasi.

Tahap selanjutnya dari 25 variabel setelah melalui Analisis statistik deskriptif didapatkan urutan variabel yang paling jarang menyebabkan hingga yang paling sering menjadi faktor hambatan pada pengadaan jasa konsultan secara e-seleksi adalah sebagai berikut:

Tabel 9. Faktor-faktor hambatan rangking 1 (satu) sd rangking 7 (tujuh)

\begin{tabular}{|lr|l|l|r|}
\hline \multicolumn{2}{|l|}{ No } & & \multicolumn{1}{|c|}{ Keterangan } & Mean \\
\hline 1. & X06 & $=$ & $\begin{array}{l}\text { Tenaga Ahli tetap } \\
\text { perusahaan }\end{array}$ & 3,42 \\
\hline 2. & X05 & $=$ & $\begin{array}{l}\text { Jumlah } \\
\text { Pengalaman }\end{array}$ & 3,34 \\
\hline
\end{tabular}




\begin{tabular}{|c|c|c|c|}
\hline No & & Keterangan & Mean \\
\hline & & perusahaan & \\
\hline 3. X11 & $=$ & $\begin{array}{l}\text { Dokumen } \\
\text { penawaran tidak } \\
\text { lengkap }\end{array}$ & 3,10 \\
\hline 4. $\mathrm{X} 13$ & $=$ & $\begin{array}{l}\text { Spesifikasi teknis } \\
\text { kurang dari yang } \\
\text { di syaratkan }\end{array}$ & 3,06 \\
\hline 5. $\mathrm{X} 12$ & $=$ & $\begin{array}{l}\text { Kualifikasi } \\
\text { personil } \\
\text { manajerial untuk } \\
\text { pelaksanaan } \\
\text { pekerjaan tidak } \\
\text { sesuai }\end{array}$ & 3,05 \\
\hline 6. X08 & $=$ & $\begin{array}{l}\text { Jumlah Peserta } \\
\text { yang lulus } \\
\text { kualfikasi kurang } \\
\text { dari } 3 \text { peserta }\end{array}$ & 3,05 \\
\hline 7. $\mathrm{X} 14$ & $=$ & $\begin{array}{l}\text { Kualifikasi } \\
\text { Personil tim } \\
\text { proyek tidak } \\
\text { sesuai }\end{array}$ & 3,01 \\
\hline
\end{tabular}

\section{Pembahasan hasil analisis}

Hasil analisis data didapatkan 25 variabel yang menjadi faktor hambatan pada pengadaan jasa konsultan secara e-seleksi di Pemerintah Provinsi DKI Jakarta. Pembahasan yang akan dilakukan oleh peneliti kepada variabel yang memiliki nilai mean diatas 3,0 yaitu ada 7 variabel.

1. Setelah pemberian waktu perpanjangan, tidak ada peserta yang menyampaikan dokumen kualifikasi yang disebabkan karena Tenaga Ahli tetap perusahaan (X6), Tenaga ahli tetap merupakan merupakan personel tim inti dari sebuah perusahaan konsultan dan konstruksi bertanggung jawab untuk menangani suatu pekerjaan dan merupakan kemampuan perusahaan dalam memiliki kinerja yang akan dicapai. Untuk perusahaan konsultan atau konstruksi dengan kualifikasi kecil, Dewan
Pengembangan Layanan usaha jasa konstruksi hanya mempersyaratkan tenaga ahli tetap yang berpengalaman dengan minimal pendidikan menengah/ sederajat, sedangkan tenaga tetap dengan Klasifikasi SBU yang disyaratkan (Untuk Usaha Kecil) pada dokumen pengadaan dan 1 (satu) orang Tenaga tetap Bersertifikat Ahli (SKA) yang sesuai dengan Subklasifikasi SBU yang disyaratkan pada dokumen pengadaan (Untuk Usaha Menengah dan Besar) (Rusmadi, Syahrudin, dan Rafie 2016)

2. Setelah pemberian waktu perpanjangan, tidak ada peserta yang menyampaikan dokumen kualifikasi yang disebabkan karena Jumlah Pengalaman perusahaan (X5), Metode penilaian terhadap metode kualifikasi ini terdiri atas 2 metode, yaitu Prakualifikasi dan Paska kualifikasi. Metode prakualifikasi adalah proses kualifikasi kontraktor sebagaimana diwajibkan oleh peraturan dalam proyek konstruksi pemerintah sebelum kontraktor menyampaikan dokumen penawaran atau mengajukan proposal (Clough, 1986). Metode pemilihan secara Prakualifikasi jumlah pengalaman perusahaan sangat berpengaruh terhadap keberhasilan peserta seleksi dalam proses penilaian kualifikasi untuk dapat lanjut ketahapan seleksi yang diatur dalam dokumen prakualifikasi (Peraturan LKPP, 2018 dan Permen PUPR, 2020).

Pengalaman perusahaan merupakan reputasi terhadap proyek sebelumnya dan atribut perusahaan merupakan hal yang penting untuk menilai prakualifikasi kontraktor (Chandra 2003)

3. Dalam proses evaluasi dokumen pemilihan disebabkan karena Dokumen penawaran tidak lengkap (X11), Proses penawaran adalah salah satu proses terpenting dalam proyek konstruksi. Proyek konstruksi melibatkan proses pengadaan yang rumit dan sulit. Satu tahapan penting adalah proses penawaran, di mana jumlah nilai keuntungan ditentukan secara kritis dan membutuhkan banyak waktu dan upaya (Arslan et al. 2006). Untuk dapat mengikuti tender penyedia jasa harus mengajukan 
dokumen penawaran yang ditujukan kepada Panitia tender. Penyedia jasa harus membuat dokumen penawaran secara realistis untuk dapat memenangkan tender (Arslan et al. 2006). Dokumen penawaran yang pertama saat tender adalah surat penawaran. Surat penawaran adalah surat yang diketik dengan mencantumkan masa berlaku penawaran, harga penawaran, dan jangka waktu pelaksanaan pekerjaan serta daftar lampiran persyaratan yang tercantum di dalam dokumen pengadaan (LKPP, 2018).

Supaya berhasil dalam mengikuti e-tender jasa konstruksi pada proyek pemerintah, penyedia jasa agar lebih teliti memperhatikan kelengkapan dan persyaratan masing - masing kegiatan yang dilelangkan sebelum melakukan pendaftaran (Prihatini, Malik, dan Komara 2017) serta perlu diberikannya pembinaan serta bimbingan teknis kepada karyawan perusahaan penyedia jasa khususnya di bidang administrasi penawaran (Prihatini, Malik, dan Komara 2017).

4. Dalam proses evaluasi dokumen pemilihan disebabkan karena Spesifikasi teknis kurang dari yang di syaratkan (X13), Ketidakjelasan dalam penulisan spesifikasi, seperti perbedaan antara jumlah biaya, gambar dan spesifikasi, dan dokumen tender yang dipersiapkan dengan tidak benar adalah masalah umum yang terkait dengan dokumen tender di Inggris menurut (Brook, 2004).

(Shash 1998) juga mengidentifikasi kejelasan spesifikasi pekerjaan sebagai salah satu faktor yang memengaruhi kontraktor dalam menaikkan nilai

penawaran. Neufville \& King (1991) menemukan bahwa kualitas desain adalah salah satu faktor yang sering dikaitkan dengan tingkat kenaikan harga. Pemilik proyek akan mendapatkan penawaran harga yang lebih baik ketika mereka memberikan gambar dan lingkup kerja yang jelas, spesifikasi yang jelas, dan instruksi yang jelas tentang apa yang harus diserahkan dalam penawaran (Laryea dan Hughes 2011).

Apabila terdapat spesifikasi yang kurang jelas pokja pemilihan perlu membuat penegasan bahwa spesifikasi yang digunakan adalah yang terdapat pada buku spesfikasi/RKS dan gambar, bukan spesifikasi yang disebutkan dalam BQ (Handoza 2013).

5. Dalam proses evaluasi dokumen pemilihan disebabkan karena Kualifikasi personil manajerial untuk pelaksanaan pekerjaan tidak sesuai (X12), (Sporrong 2011) berpendapat bahwa ketersediaan personil manajerial merupakan salah satu kriteria penting dalam pemilihan kontraktor. Meskipun personil inti/manajerial dibahas sebagai kriteria seleksi yang penting, sedikit penelitian tentang bagaimana menilai personil inti /majerial telah terdokumentasikan didalam studi literatur dan bagaimana pentingnya hal tersebut pada proses seleksi tender konstruksi (Abdul, M. and Andreas 2013). Pelaksanaan e-tender jasa konsultan atau konstruksi di Indonesia mewajibkan kontraktor memiliki kualifikasi personil manajerial yang telah bersertifikat (LKPP, 2018)

6. Dalam proses evaluasi dokumen kualifikasi disebabkan karena jumlah peserta yang lulus kualifikasi kurang dari 3 peserta (X8), Sistem pengadaan dengan prakualifikasi dua sampul menggunakan sistem penilaian kualitas dan biaya, pada saat penilaian kualifikasi perusahaan yang lulus kualifikasi dengan jumlah 3 (tiga) peserta seleksi. Prakualfikasi jumlah perusahaan harus terpenuhi syarat daftar pendek yang telah ditetapkan tersebut (Mangitung 2010).

Metode penilaian terhadap metode kualifikasi ini terdiri atas 2 metode, yaitu Prakualifikasi dan Paskakualifikasi. Metode prakualifikasi adalah proses kualifikasi kontraktor sebagaimana yang diwajibkan oleh peraturan dalam proses pemilihan konsultan pemerintah sebelum peserta menyampaikan dokumen penawaran harga 
peserta menyampaikan klasifikasi perusahaan diantaranya pengalaman perusahaan, dan kepemilikan tenaga ahli tetap (Sporrong 2011).

7. Dalam proses evaluasi dokumen pemilihan disebabkan karena Kualifikasi personil tim proyek tidak sesuai (X12), Personel tim inti dari sebuah perusahaan konstruksi bertanggung jawab untuk menangani aspek manajerial dan teknis. Untuk perusahaan konstruksi kecil, Dewan Pengembangan Layanan usaha jasa konstruksi hanya mempersyaratkan teknisi yang berpengalaman, sedangkan ahli teknik yang berpengalaman diperlukan untuk perusahaan menengah dan besar, namun untuk perusahaan menengah dan besar masih wajibkan memiliki ahli Teknik yang berpengalaman dan berkualitas untuk setiap bidang utama pekerjaan konstruksi yang memenuhi persyaratan mereka (Mangitung 2010). Pelaksanaan e-seleksi jasa konsultan di Indonesia mewajibkan kontraktor memiliki Kualifikasi Personil tim proyek sesuai dengan dokumen pemilihan yang ditetapkan oleh pokja (Rusmadi, Syahrudin, dan Rafie 2016), yang terdiri paling sedikit 1 (satu) orang Tenaga Tetap Bersertifikat Terampil (SKT) yang sesuai dengan Klasifikasi SBU yang disyaratkan (Untuk Usaha Kecil) pada dokuemen pengadaan dan 1 (satu) orang Tenaga tetap Bersertifikat Ahli (SKA) yang sesuai dengan Subklasifikasi SBU yang disyaratkan pada dokumen pengadaan (Untuk Usaha Menengah dan Besar) (Rusmadi, Syahrudin, dan Rafie 2016).

\section{KESIMPULAN}

Kesimpulan dari penelitian dan akan dilanjutkan dengan saran terhadap hambatan pada pengadaan jasa konsultan secara e-seleksi di Pemerintah Provinsi DKI Jakarta, setelah melalui sistematika penulisan untuk dapat menjawab tujuan penelitian, maka dapat diambil kesimpulan sebagai berikut:

1. Hasil dari analisis data deskriptif diperoleh bahwa hasil hipotesa dalam penelitian ini dihasilkan 7 (tujuh) faktorfaktor dominan yang menjadi hambatan pada pengadaan jasa konsultan secara eseleksi di Pemerintah Provinsi DKI Jakarta adalah:

- rangking 1 (satu) meliputi faktor tenaga ahli tetap perusahaan (X6),

- rangking 2 (dua) meliputi faktor jumlah pengalaman perusahaan (X5),

- rangking 3 (tiga) dokumen penawaran tidak lengkap (X11),

- rangking 4 (empat) spesifikasi teknis kurang dari yang disyaratkan (X13),

- rangking 5 (lima) Kualifikasi personil manajerial untuk pelaksanaan pekerjaan tidak sesuai (X12),

- rangking 6 (enam) jumlah peserta yang lulus kualifikasi kurang dari 3 peserta (X8) dan

- rangking 7 (tujuh) Kualifikasi Personil tim proyek tidak sesuai (X14).

2. Rekomendasi tindakan untuk meminimalkan faktor-faktor hambatan pada pengadaan jasa konsultan secara eseleksi di Pemerintah Provinsi DKI Jakarta. Setelah mendapat urutan faktorfaktor mulai dari yang paling sering terjadi terhadap penyedia jasa konsultan, oleh karena itu penulis melakukan studi literatur agar diketahui penyebab hambatan sehingga dapat meminimalkan dan mengatasi hambatan tersebut.

\section{DAFTAR PUSTAKA}

[1] Abdul, M. and Andreas, F.V.R. 2013. "Kajian Dan Evaluasi Pemilihan Konsultan." Konstruksia 5(1): 19.

[2] Arslan, Gökhan, Mustafa Tuncan, M. Talat Birgonul, dan Irem Dikmen. 2006. "E-bidding proposal preparation system for construction projects." Building and Environment 41(10): 1406-13.

[3] Budianto, D., Rarasati, A. D., \& Nursin, A. (2021). Strategy for increasing tender success in Jakarta's e-tender construction project. IOP Conference 
Series: Materials Science and Engineering, 1098(2), 022052.

[4] Hardjomuljadi, S. (2016). Variation order, the causal or the resolver of claims and disputes in the construction projects. International Journal of Applied Engineering Research, 11(14), 8128-8135.

[5] Lembaga Kebijakan Pengadaan Barang/Jasa Pemerintah. (2019). Sistem Informasi Rencana Umum Pengadaan.

https://sirup.lkpp.go.id/sirup/ro

[6] LKPP. (2018). Perka LKPP Nomor 9 Tahun 2018 tentang Pedoman Pelaksaan Pelaksanaan Pengadaan Barang/Jasa Melalui Penyedia.

[7] LKPP. (2019a). Apa Yang Dimaksud Dengan Aplikasi SIKaP? https://eproc.lkpp.go.id/faq/read/16 /apa-yang-dimaksud-denganaplikasi-sikap

[8] LKPP. (2019b). Optimalisasi Anggaran Belanja Barang/Jasa Pemerintah 150 Triliun.

http://www.lkpp.go.id/v3/\#/read/5 698

[9] Mangitung, Donny M. 2010. “Typical contractor prequalification characteristics of public procurement practices in Indonesia." COBRA 2010 Construction, Building and Real Estate Research Conference of the Royal Institution of Chartered Surveyors (January).

[10] Ndou, V. D. (2004). E - Government for Developing Countries: Opportunities and Challenges. The Electronic Journal of Information Systems in Developing Countries, 18(1), 1-24.

[11] Neufville, R., \& King, D. (1991). Risk and need-for-work premiums in contractor bidding. Journal of Construction Engineering and Management, 117(4), 659-673.

[12] Peraturan Menteri Pekerjaan Umum Nomor 31/PRT/M/2015 Tentang Standar Dan Pedoman Pengadaan
Pekerjaan Konstruksi dan Jasa Konsultan, (2015).

[13] Peraturan Presiden RI Nomor 16 Tahun 2018 tentang Pengadaan Barang/Jasa Pemerintah, (2018).

[14] Prihatini, Liya, Alfian Malik, dan Ryan Tri Komara. 2017. "Evaluasi kegagalan penyedia jasa konstruksi dalam proses pengadaan jasa konstruksi dengan sistem elektronik (." Jurnal Online Mahasiswa Fakultas Teknik Universitas Riau 4(1): 1-10.

[15] Rusmadi, Syahrudin, dan Rafie. 2016. "Proses Evaluasi Penawaran Pengadaan Pekerjaan." Jurnal Mahasiswa Teknik Sipil Universitas Tanjungpura.

[16] Sporrong, Josefin. 2011. "Criteria in consultant selection: Public procurement of architectural and engineering services." Australasian Journal of Construction Economics and Building 11(4): 59-76. 
